\title{
Oxygen and carbon isotope anomalies in the ultrahigh pressure metamorphic rocks of the Dabie-Sulu terranes: implications for geodynamics
}

*Department of Earth and Space Sciences, University of Science and Technology of China, Hefei 230026, China

Unusual isotope compositions of oxygen and carbon have been found in the ultrahigh pressure (UHP) metamorphic rocks of the Dabie-Sulu terranes, East China. Eclogites and coexisting coesite-bearing gneiss show negative $\delta^{18} \mathrm{O}$ values as low as -10 to $-2 \%$ relative to SMOW, while coesite-bearing marble associated with the eclogites has high $\delta{ }^{13} \mathrm{C}$ values up to $+6 \%$ relative to $P D B$. The negative $\delta^{18} \mathrm{O}$ values in the UHP rocks must be acquired by water-rock interaction between the precursors of the rocks and meteoric water prior to eclogite facies metamorphism, because oxygen isotope equilibrium has been preserved between different mineral pairs from the rocks which precludes hydrothermal alteration during exhumation. The positive $\delta{ }^{13} \mathrm{C}$ values in the UHP marble are interpreted to represent the carbon isotope composition of premetamorphic limestone, because there is no known process to enrich carbonate in $\delta{ }^{13} \mathrm{C}$ during regional metamorphism. The carbon isotope anomaly in the protolith of the marble suggests a local change in the redox state of water during deposition of limestone. Therefore, the Dabie area was a continental marginal basin that became consuming due to convergence prior to collision between the Yangtze and Sino-Korean plates. Survival of the unusually negative $\delta$ ${ }^{18} \mathrm{O}$ and positive $\delta{ }^{13} \mathrm{C}$ values in the UHP rocks suggests that there was no significant isotopic exchange with the mantle during the subduction of supracrustal rocks to mantle depths. Because eclogitic and gneissic minerals undergo rapid oxygen isotope exchange by diffusion and recrystallization at mantle pressures and temperatures, preservation of meteoric water signature in the rocks implies a short residence time and a fluid-absent environment for the UHP slab at mantle depths. The consistency of oxygen isotope geothermometries for different mineral pairs suggests a rapid cooling and ascent process for the UHP eclogites subsequent to their formation at mantle depths and a lack of fluid during exhumation.

\section{Introduction}

The identification of coesite and micro-diamond in the metamorphic rocks of the Dabie and Sulu terranes implies that the crustal materials can be subducted to mantle depths of at least $100 \mathrm{~km}$ (Okay et al., 1989; Wang et al., 1989; Xu et al., 1992). In the terranes, ultrahigh pressure (UHP) minerals such as coesite are found as inclusions in garnet in eclogite boudins. Coesite and aragonite inclusions within garnet and dolomite are also observed in biotite gneiss and marble that host the eclogites (Wang and Liou, 1991; Schertl and Okay, 1994; Zhang and Liou, 1996). These indicate that the biotite gneiss, marble and associated eclogites shared the same UHP metamorphic event. An UHP metamorphic unit has been recognized in the Dabie Mountains and the Sulu terrane which is predominantly quartzofeldspathic gneisses with minor pods and bands of eclogite, marble, quartz schist and rare ultramafic rocks (Okay, 1993; Cong et al., 1995; Wang et al., 1995; Zhang et al., 1995). The UHP unit is surrounded by granitic gneisses which show no mineralogical evidence for their having experienced the UHP metamorphism. The DabieSulu metamorphic complex marks the suture zone of a continentcontinent collision between the Yangtze and Sino-Korean plates (Figure 1). Isotope dating by mineral $\mathrm{Sm}-\mathrm{Nd}$ isochron ( $\mathrm{Li}$ et al., 1993) and zircon U-Pb discordia (Ames et al., 1996) yields consis-

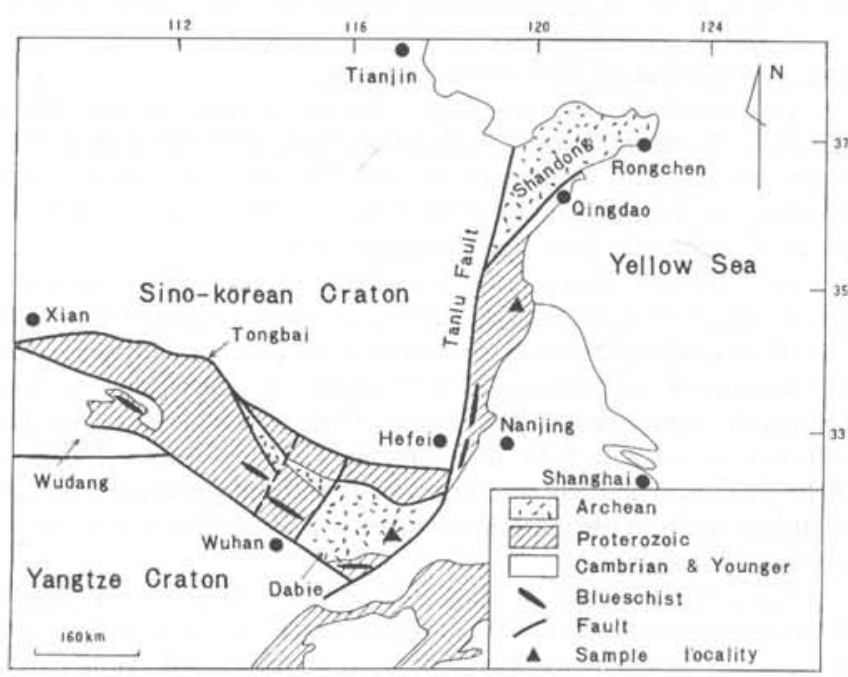

Figure 1 Tectonic setting of the Dabie-Sulu terranes in East China, showing Yangtze craton to the south and Sino-Korean craton to the north. Eastern part of collision zone is offset by Tanlu fault to the northeast (modified after Wang et al., 1989). 
tent ages of Triassic (210 to $230 \mathrm{Ma}$ ) for formation of the UHP eclogites.

Within the framework of forming the UHP metamorphic rocks by plate subduction to mantle depths, it is unclear whether the precursors of the UHP rocks were subjected to significant interaction with the surrounding mantle. Stable isotope studies can be helpful in this aspect because there are distinct difference in carbon, oxygen and hydrogen isotopes between sedimentary rocks, surface waters (meteoric water and/or sea water) and the mantle. Furthermore, stable isotope analyses of high to ultrahigh pressure metamorphic rocks can be used to determine whether isotopic compositions are largely inherited from premetamorphic protoliths or, alternatively, if compositions have been modified by the infiltration of external fluids. This paper summarizes our studies on the carbon, oxygen and hydrogen isotopes in eclogites, marble, biotite gneiss and granitic gneiss from the eastern Dabie and western Sulu. The eclogites, marble and biotite gneiss contain coesite and thus belong to the UHP slab which is enclosed by the granitic gneiss experienced amphibolite facies metamorphism (Okay, 1993; Cong et al., 1995; Zhang et al., 1995).

\section{Oxygen isotope anomaly}

It is well known that the $\delta^{18} \mathrm{O}$ values of the Earth's surface water are between $0 \%$ (sea water) and $-20 \%$ (meteoric water, depending on altitude). Metamorphic rocks have oxygen isotope compositions that are usually similar to those of igneous and sedimentary, with $\delta^{18} \mathrm{O}$ values ranging from +6 to $+18 \%$, depending on the geochemical nature of protolith (e.g., Hoefs, 1987; Sharp et al., 1993). Unusually low $\delta^{18} \mathrm{O}$ values have been reported in granulites from Australia $(+0.1$ to $+6.8 \% \hat{\mathrm{I}})$, Adirondack anorthosites $(+3$ to $+5.8 \%$ ) and wollastonite skarns $(-1.3$ to $+7.0 \%)$ from USA, and amphibolite-facies gneiss from Scottish Highlands $(-3$ to $+8 \%$ ) (see summary by Zheng et al., 1996). Both continental and oceanic eclogites have been commonly found to have low $\delta^{18} \mathrm{O}$ values: +1.5 to +8.9 in the Alps, +2.9 to $+8.0 \%$ in Norway, +2.2 to $+8.1 \%$ in South Africa (see summary by Zheng et al., 1996). Only Siberian eclogites have uniformly higher $\delta^{18} \mathrm{O}$ values of 5.4 to $7.2 \%$ (Jacob et al., 1994), which are close to, but slightly greater than average mantle $\delta^{18} \mathrm{O}$ values of $+5.7 \%$ (Hoefs, 1987). The presence of the low $\delta^{18} \mathrm{O}$ values in granulites and eclogites indicates the direct or indirect involvement of seawater or meteoric water in the formation of the high-grade metamorphic rocks.

Exceptionally low negative $\delta^{18} \mathrm{O}$ values of -10 to $-8 \%$ relative to SMOW were found in mineral separates from an eclogite pod (containing quartz-schist bands) at a hilltop Qinglongshan of the Donghai district in the western part of the Sulu terrane (Yui et al., 1995; Zheng et al., 1996). These are the lightest oxygen isotope compositions so far reported for metamorphic rocks in the world. It is at this eclogite pod that $\mathrm{Li}$ et al. (1994) found excess argon in phengite. The most probable reason for such low $\delta^{18} \mathrm{O}$ values is isotopic exchange with ancient meteoric water prior to eclogitization. This provides compelling evidence for preservation of pre-metamorphic isotope signature during the UHP metamorphism at mantle depths. Limited crust-mantle interaction is thus inferred between the $\delta^{18} \mathrm{O}$ depleted eclogites and the mantle when the slab containing the eclogite protoliths was subducted to mantle depths.

Our studies show that the mineral separates of eclogites from the Shuanghe district in the eastern part of the Dabie Mountains have $\delta^{18} \mathrm{O}$ values of -2 to $+7 \%$, while those from the Donghai district (except the samples from the hilltop Qinglongshan) in the western part of the Sulu terrane have $\delta^{18} \mathrm{O}$ values of -5 to $+5 \%$. Oxygen isotope equilibrium has been approached between the eclogitic minerals. This not only yields the concordant isotope temperatures of $550^{\circ} \mathrm{C}$ to $750^{\circ} \mathrm{C}$, but also suggests that the eclogites have acquired the unusual $\delta^{18} \mathrm{O}$ values prior to exhumation and probably the UHP metamorphism. Therefore, the eclogite protolith underwent hydrothermal alteration by the fluid of surface water origin prior to or during subduction. Hydrogen isotope ratios of phengite from the eclog-

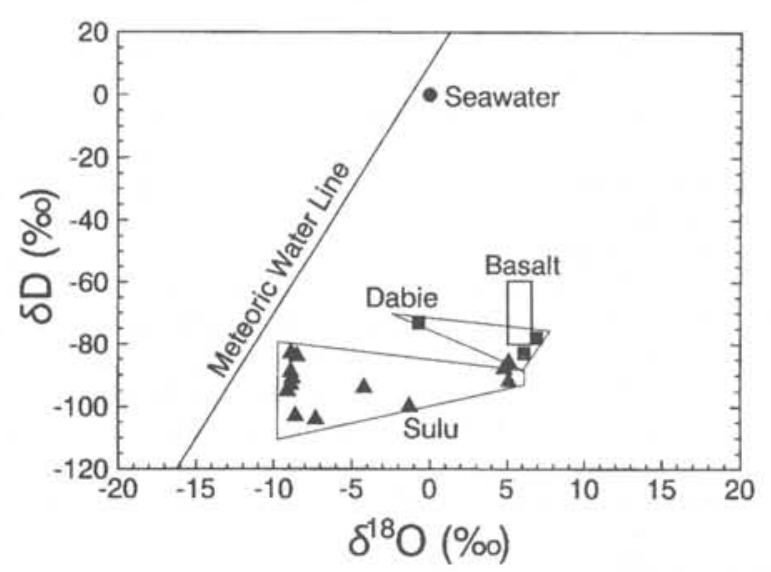

Figure 2 Hydrogen and oxygen isotope compositions of phengite in the eclogites from Shuanghe in the eastern Dabie Mountains (square) and Donghai in the western Sulu terrane (triangles). Also shown is the range of normal basalts for comparison (Hoefs, 1987).

ites range from - 104 to $-73 \%$ (Figure 2), indicating the involvement of meteoric water rather than seawater.

There is a significant difference in $\delta^{18} \mathrm{O}$ values between the two gneisses from Shuanghe in the eastern Dabie. The biotite gneiss containing coesite inclusions in garnet has a large variation in $\delta^{18} \mathrm{O}$ values from -4.7 to $+10.3 \%$ which are positively correlated with the $\delta^{18} \mathrm{O}$ variation for the associated eclogites, whereas the $\delta^{18} \mathrm{O}$ values of the granitic gneiss which only experienced the amphibolite facies metamorphism vary only from -4.2 to $+0.8 \%$. Oxygen isotope equilibrium has been attained and preserved among various minerals in the gneisses. Because no significant shift in the oxygen isotope composition of the gneisses was controlled by retrograde exchange processes during cooling of the rocks and by net-transfer reactions during prograde and retrograde metamorphism, the $\delta^{18} \mathrm{O}$-depletion of both gneisses is interpreted, like the eclogites, to result from the infiltration of surface water into the rocks prior to exhumation and probably the UHP metamorphism. Hydrogen isotope ratios vary from -78 to $-109 \%$ for phengite and biotite from both gneisses (Figure 3), which are similar to the associated eclogites (Figure 2). The low $\delta \mathrm{D}$ values for the micas indicate a fluid of meteoric water origin for the hydrothermal alteration prior to or during subduction.

It appears that there are oxygen isotope heterogeneities on a local scale of tens or hundreds of meters in given localities of the Dabie-Sulu terranes. However, since the eclogites are separate "pods" or "boudins", they could have been many kilometers apart

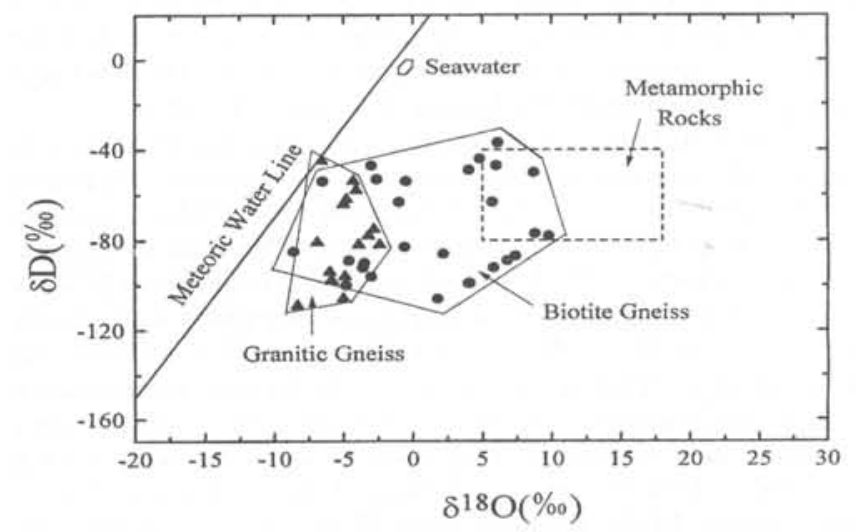

Figure 3 Hydrogen and oxygen isotope compositions of phengite and biotite from biotite gneiss (circles) and granitic gneiss (triangles) at Shuanghe in the eastern part of the Dabie Mountains. Also shown is the range of normal metamorphic rocks for comparison (Hoefs, 1987). 
from each other during the UHP metamorphism. The large $\delta^{18} \mathrm{O}$ variations from -10 to $+5 \%$ in the Donghai eclogites and from -2 to $+7 \%$ in the Shuanghe eclogites can be explained by one of the following processes: (1) heterogeneous water-rock interaction prior to the UHP metamorphism; (2) isotopic exchange with crustal fluids during subduction (prograde metamorphism) and/or exhumation (retrograde metamorphism); and (3) heterogeneous crust-mantle interaction during the UHP metamorphism. It is possible that there would be variable isotope exchange with the channelized fluid of meteoric water origin during the hydrothermal alteration of the eclogite precursors. Likewise, crustal fluids could be interacted with the eclogite precursors during subduction. In either case, the complete preservation of premetamorphic isotope signature in the eclogites is implied, so that the UHP metamorphism would not have erased the isotopic signature of meteoric water in the eclogites, but isotopic equilibration was achieved among the minerals at the formation temperature of the eclogites.

It is also possible that there could exist variable degrees of isotopic exchange between the hydrothermally altered and $\delta^{18} \mathrm{O}$ depleted eclogite precursors and the mantle materials through fluid phase or metamorphic reaction during the UHP metamorphism at mantle depths. Although the fluid phase expelled from the hydrothermally altered and metamorphosed eclogite precursors would be of small amounts, it is of considerable importance in promoting isotopic exchange between the eclogites and mantle. The processes could have played a role in changing the $\delta^{18} \mathrm{O}$ values of the eclogites and their precursors, but we cannot distinguish between them at the present time. The preservation of oxygen isotope equilibrium between the different mineral pairs within the eclogites rules out the significant interaction with crustal fluids during exhumation. Therefore, the survival of the extreme $\delta^{18} \mathrm{O}$-depletion in the eclogites suggests a lack of fluid during the UHP metamorphism and subsequent exhumation. Furthermore, the extremely low $\delta \mathrm{D}$ and $\delta^{18} \mathrm{O}$ values of -104 to $-100 \%$ for phengite and -10 to $-9 \%$ for the eclogites from Qinglongshan in the western Sulu terrane track the oxygen and hydrogen isotope compositions of ancient meteoric water at some time earlier than that of the UHP metamorphism at Triassic.

\section{Carbon isotope anomaly}

The marble is associated with the eclogites in the eastern Dabie and is mainly composed of calcite (and its pseudomorphs after aragonite) and minor dolomite. They occur in either pure or impure forms. The impure marble contains garnet, clinopyroxene, phengite, epidote, rutile, quartz (and its pseudomorph after coesite), and rare pargasite and epidote. As shown in Figure 4 , there is a wide range of $\delta^{13} \mathrm{C}$ from +1.7 to $+5.7 \%$ relative to $\mathrm{PDB}$ and of $\delta^{18} \mathrm{O}$ from +5.8 to $+22.9 \%$ relative to SMOW for the marble associated with the UHP eclogites in the eastern part of the Dabie Mountains. There is rough correspondence between the highest $\delta^{13} \mathrm{C}$ and $\delta^{18} \mathrm{O}$ values.

Carbon from the normal marine carbonates has $\delta^{13} \mathrm{C}$ close to $0 \pm 2 \%$ and other sedimentary lithologies usually have isotopically lighter carbon than marine limestone, while sedimentary limestones typically have the $\delta^{18} \mathrm{O}$ values greater than $+25 \%$ due to temperature effect (Hoefs, 1987). In general, marbles with $\delta^{18} \mathrm{O}<+20 \%$ are likely to have interacted with significant quantities of externally derived fluid (Valley, 1986). The decrease in both $\delta^{13} \mathrm{C}$ and $\delta^{18} \mathrm{O}$ can be ascribed to either metamorphic devolatilization or interaction with a $\mathrm{H}_{2} \mathrm{O}$-dominant fluid. It is known that metamorphic devolatilization will result in depletion of a few per mille in both $\delta^{13} \mathrm{C}$ and $\delta^{18} \mathrm{O}$ in the absence of external fluid infiltration (Valley, 1986; Hoefs, 1987). Diffusion-controlling isotope exchange with graphite is unlikely because the marbles do not contain graphite from inspection under microscope. No graphite-bearing metasediment occurs within the eclogites and gneisses associated with the marbles (Okay et al., 1993; Cong et al., 1995; Wang et al., 1995). There is no other geochemical process to enrich carbonate in $\delta^{13} \mathrm{C}$ during regional metamorphism (Valley, 1986; Hoefs, 1987). Therefore, the

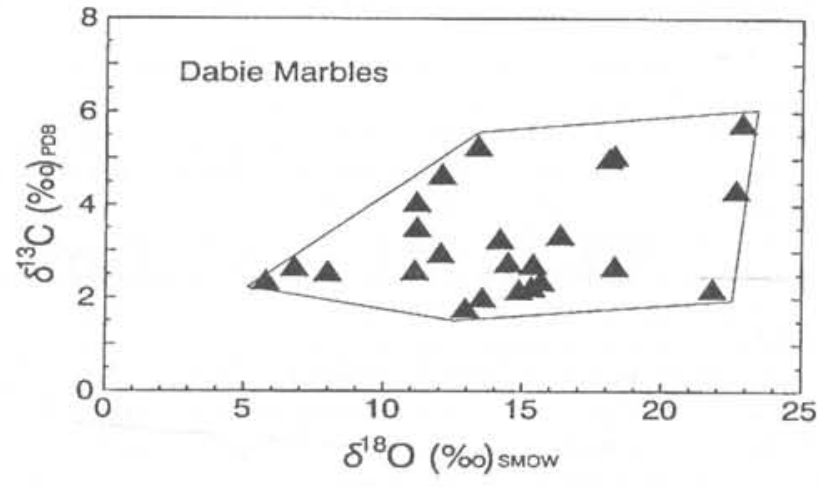

Figure 4 Carbon and oxygen isotope compositions of marbles associated with the eclogites from Shuanghe, Shima, Wumiao, Hengcong, Xindian, Laoyoufang and Xinyoufang in the eastern part of the Dabie Mountains.

greatest $\delta^{13} \mathrm{C}$ values for the marbles presumably approach values for the premetamorphic isotopic compositions of limestone (Valley, 1986; Baker and Fallick, 1989). Mantle carbonatites normally have $\delta^{13} \mathrm{C}$ values between -3 to $-7 \%$ (Hoefs, 1987), which are significantly different from the $\delta^{13} \mathrm{C}$ values of the marbles in question. In this regard, the limestone, the protolith of the Dabie marbles, was of the high $\delta^{13} \mathrm{C}>+6 \%$.

Carbon isotope excursion in sedimentary carbonates has been noted from major boundary intervals in stratigraphy, including the Neoproterozoic-Cambrian, the Cambrian-Ordovician, the Ordovician-Silurian, the Paleozoic-Mesozoic and Mesozoic-Cenozoic (Magaritz, 1991; Ripperdan, 1994). The secular $\delta^{13} \mathrm{C}$ trend can be caused by changes in the balance of fluxes in marine carbon cycle, with inputs from magma degassing, rivers, and oxidation of organic matter and outputs that include production of marine carbonates and organic matter. Extraordinary $\delta^{13} \mathrm{C}$ enrichment in local carbonates is known from a number of environments. Some minor high $\delta^{13} \mathrm{C}$ carbonates were sometimes formed as the result of fermentative diagenesis during burial of organic-rich sediments. Moderately $\delta^{13} \mathrm{C}$ enriched carbonates are known from present-day evaporitic and hypersaline environments (Stiller et al., 1985). High $\delta^{13} \mathrm{C}$ carbonates are also found in hot springs (Friedman, 1970). The increase in the $\delta^{13} \mathrm{C}$ of marine limestone is generally interpreted as a result of enhanced organic storage in sediments due to a decrease in oxygen fugacity (e.g., Holland, 1984: Marshall and Middleton, 1990). Apparently, carbon isotope anomalies in sedimentary carbonates are associated with a shift in water composition corresponding to the particular environment of deposition.

Carbon isotope studies of marble can be used to trace the sedimentary environment of their protolith (limestones). The $\delta^{13} \mathrm{C}$ enrichment in the Dabie marble requires the deposition environment of a marginal basin to decrease the oxygen fugacity of water or increase the deposition rate of organic carbon. The convergence of the Yangtse and Sino-Korean cratons prior to collision is the plausible cause to change the redox state of basin water. In this context, the Dabie area would be a continental marginal basin which was consumed during the convergence between the Yangtze and SinoKorean plates.

\section{Geodynamic implications}

The mantle normally has the $\delta^{13} \mathrm{C}$ values of about $-5 \%$ (Hoefs, 1987). Any chemical interaction (e.g., isotopic exchange) between the crustal marble and the mantle material would adjust the marble $\delta^{13} \mathrm{C}$ values to the mantle values. The preservation of the unusually positive $\delta^{13} \mathrm{C}$ values of +5 to $+6 \%$ for the marbles associated with the eclogites in the Dabie Mountains indicates limited carbon isotope 
exchange between the subducted rocks and the surrounding mantle materials at the mantle depths. The marble precursor (limestone) has kept its isotopic signature during the UHP metamorphism and subsequent exhumation. This implies that the carbon isotope exchange was very limited even at very high pressures and temperatures of plate subduction to mantle depths.

The Dabie orogenic complex was truncated at its eastern end by the 'Tan-Lu fault, off-setting it by a minimum of $530 \mathrm{~km}$ northwards to result in the Sulu terrane (Figure 1). The unusually negative $\delta^{18} \mathrm{O}$ values of -10 to $-9 \%$ were found in eclogites and interlayered quartzschist from Qinglongshan in the western part of the Sulu terrane (Yui et al., 1995; Zheng et al. 1996). The eclogites from Shuanghe in the eastern part of the Dabie Mountains and those from the other outcrops of the Donghai district in the western part of the Sulu terrane also have low $\delta^{18} O(-5 \sim+7 \%$ ) and $\delta \mathrm{D}(-104 \sim-73 \%$ ) values (Figure 2). These have been interpreted to indicate that eclogite precursors (a type of basaltic rocks) resided on continental crust and underwent hydrothermal alteration by ancient meteoric water prior to eclogite-facies metamorphism. Survival of the unusual $\delta^{18} \mathrm{O}$ signature in the Qinglongshan eclogites also suggests very limited exchange of oxygen isotopes between the hydrothermally altered eclogite precursors and the surrounding mantle materials under UHP metamorphic conditions. It also rules out the isotopic exchange of the eclogites with crustal fluids during subduction and exhumation. The above interpretations are consistent with the conclusion reached from the carbon isotope anomaly in the marbles associated with the eclogites in the eastern part of the Dabie Mountains. In this context, there was only restricted crust-mantle interactions when the plate containing the precursors of both eclogite and marble was subducted to the mantle depths greater than $100 \mathrm{~km}$.

The elfect of pressure on the rate of oxygen isotope exchange between carbonate and silicate minerals has been experimentally examined in the pressure range of I to 23 kbar under nominally anhydrous conditions (e.g. Chiba ct al.. 1989; Rosenbaum and Mattey, 1995). Diffusion and recrystallization are recognized as the ratelimiting step in the exchange experiments. There is a tens-fold increase in the percentage of exchange with increasing pressure. It can thus be expected that the rate of oxygen isotope exchange at mantle pressures would be sufficiently large to reequilibrate oxygen isotopes between the mantle materials and the $\delta^{18} \mathrm{O}$-depleted eclogites within the subducted slab. This would shift the eclogite $\delta^{18} \mathrm{O}$ values to the mantle $\delta^{18} \mathrm{O}$ values around +5 to $+6 \%$ and thus erase the isotopic signature of meteoric water preserved in the Dabie-Sulu eclogites. However, preservation of the unusually low $\delta^{18} \mathrm{O}$ values in the ectogites argues against significant exchange of oxygen isotopes between the mantle and the $\delta^{18} \mathrm{O}$-depleted eclogites. This suggests the limited crust-mantle interaction and a lack of fluid during the UHP metamorphism. Furthermore, this implics that the residence time of the UHP eclogites within the mantle was too short to reequilibrate oxygen isotopes between the mantle and the eclogites.

Retrograde exchange of oxygen isotopes between minerals and between mineral and fluid could occur during slow cooling of metamorphic rocks (Giletti, 1986). Oxygen diffusion is the rate-limiting step for this retrograde isotope exchange. Available oxygen self-diffusion data indicate that there are differences of several orders of magnitude in the diffusion coefficients for the eclogite minerals (Farver, 1989; Fortier and Giletti, 1989). Under slowly cooled conditions, oxygen isotope geothermometry for different mineral pairs should yield different but regular temperatures corresponding to the closure temperatures of oxygen diffusion in the minerals (Giletti, 1986; Eiler et al.. 1993). The congruence of oxygen isotope temperatures among different mineral pairs (except those involving zoisite and rutile), and the consistency of these temperatures with the temperatures derived from cation partition geothermometies, have been observed in the UHP eclogites from the Dabie-Sulu terranes. These suggest a rapid cooling and ascent of the eclogites after the UHP metamorphism and a lack of fluid during rapid exhumation.

Essentially, the lack of thuid appears to have been responsible for the metastable preservation of ultrahigh-pressure $\mathrm{SiO}_{2}$ polymorph coesite in garnets from the Dabie-Sulu eclogites, marbles and gneisses (Okay el al., 1989; Wang et al., 1989; Wang and Liou, 1991; Schert and Okay. 1994; Zhang et al.. 1995; Zhang and Liou. 1996) and even intergranular coesite along grain boundaries in the Sulu eclogites (Liou and Zhang, 1996: Liou et al., 1997). Reconnaissance experiments by Dachille et al. (1963) indicate that the transformation of coesite to quartz is sluggish in the absence of $\mathrm{H}_{2} \mathrm{O}$ Therefore, given parts of the UHP metamorphic unit would acquire the oxygen isotope anomaly during the interaction of ancient meteoric water with the premetamorphic precursors prior to the UHP metamorphism, then were isolated from fluid interaction during their descent to and return from mantle depths.

Whether the country rock gneisses of the Dabie and Sulu terranes eclogites were also subjected to the UHP metamorphism has been controversial for a Iong time. This problem was exacerbated by the poor preservation of evidence for the pre-metamorphic relationship between the eclogites and their country rocks and by the lack of UHP record in most of the gncisses. According to fluid flow model on stable isotopes, it is suggested that the $\delta^{i r}$ O-depletion of the biotite gnciss and associated eclogites is due to the infiltration of the meteoric water into the precursor rocks prior to the UHP metamorphism. Therefore, the biotite gneiss and associated eclogites experienced the same geodynamic processes and thus were part of a single tectonic entity throughout the course of subduction. UHP metamorphism and exhumation. In other words, an in-situ model is valid for formation of the UHP eclogite and biotite gneiss and thus the UHP unit was tectonically emplaced into the low-P granitic gneiss.

It has been observed that there is the uniform $\delta^{18} \mathrm{O}$-depletion in the granitic gneiss, the country rock of the UHP unit at Shuanghe in the eastern Dabic. This can be due to the water/rock interaction prior to the amphibolite facies metamorphism, but different depths of subduction are required to produce the granitic and biotite gneisses at different pressures, respectively. It is not possible that the UHP record in the granitic gneiss has been erased by fluid-present retrograde metamorphism during exhumation, because the lack of fluid has been indicated by preservation of oxygen isotope equilibrium among the gneissic mincrals. In this regard, the relationship between the UHP unit and the granitic gneiss is "foreign" rather than "in-situ" in the Dabie Mountains.

\section{Acknownledgements}

This study has been supported by funds from the Natural Science Foundation of China and the Chinese Academy of Science. The field work was benelited from assistance by Drs. Chen Jiangfeng, Fu Bin, Ge Ningjie, Jiang Laili, Li Shuguang, Liu Yicun and Zhai Mingguo. Thanks are due to Drs. Fu Bin, Gong Bing and Huang Yaosheng for their help with isotopic analyses.

\section{References}

Ames, I.., Zhou, G. Z. and Xione. B. C., 1996. Geochronology and isotopic character of ultrahigh-pressure metamorphism with implications for the collision of the Sino-Korean and Yangece cratons, central China. Tectonics, v. 15, pp. $472-489$.

Baker. A. J. and Fallick. A. E., 1989. Heavy carbon in two-billion-year-old marbles from Lofoten-Vesteralen, Noway: Implications for the Precamhrian carbon cycle. Geochim. Cosmochim. Acta. v.53, pp.1111-1115.

Chiba. H. Chacko. T.. Claylon, R. N. and Goldsmith. J. R., 1989, Oxygen isotope fractionation involving diopside, forsterite, magnetite, and calcite: Application to geothermometry. Geochim. Cosmochim. Acta, v.53, pp.2985-2995.

Cong. B. L., Zhai, M. G., Carswell, D. A.. Wilson, R. N., Wang, Q. C., Zhao, Z.. Y. and Windlcy, B. F..1995, Petrogenesis of ultrahigh-pressure rocks and their country rocks at Shuanghe in Dabieshan, Central China. Eur. J. Mineral., v.7.pp.119-138.

Dachille, F., Zeto, R. J. and Roy, R., 1963, Coesite and stishovite: Stepwise reversal transformations. Science, v. 140. pp.991-993. 
Eiler, J. M., Valley, J. W. and Baumgartner, L.P., 1993, A new look at stable isotope geothermometry. Geochim. Cosmochim. Acta, v.57, pp.257I2583.

Farver, J. R., 1989, Oxygen self-diffusion in diopside with application to cooling rate determination. Earth Planet. Sci. Lett., v.92, pp.386-396.

Fortier, S. M. and Giletti, B. J., 1989, An empirical model for predicting diffusion coefficients in silicate minerals. Science, v.245, pp.1481-1484.

Friedman, I., 1970, Some investigations of the deposition of travertine from hot springs - I. The isotopic chemistry of travertine depositing spring. Geochim. Cosmochim. Acta, v.34, pp.1303-1315.

Giletti, B. J., 1986, Diffusion effects on oxygen isotope temperatures of slowly cooled igneous and metamorphic rocks. Earth Planet. Sci. Lett. v.77, pp.218-228.

Hoefs, J,, 1987, Stable Isotope Geochemistry. 3rd Edition, Spinger-Verlag. Berlin Heidelberg New York, pp.241.

Holland, H. D., 1984, The Chemical Evolution of the Atmosphere and Oceans. Princeton University Press, pp.369.

Jacob, D., Jagoutz, E., Lowry, D., Mattey, D. and Kudrjavtseva, G., 1994. Diamondiferous eclogites from Siberia: Remnants of Archean oceanic crust. Geochim. Cosmochim. Acta, v.58, pp.5191-5207.

Li, S. G., Xiao, Y. L., Liou, D. L., Chen, Y. Z., Ge, N. J., Zhang, Z. Q., Sun, S. S., Cong, B., Zhang, R. Y., Hart, S. R. and Wang, S. S., 1993, Collision of the North China and Yangtse Blocks and formation of coesitebearing eclogites: Timing and processes. Chem. Geol., v.109, pp.89-111.

Li, S. G., Wang, S. S., Chen, Y. Z., Liu, D. L., Qiu, J., Zhou, H. X. and Zhang, Z. M., 1994, Excess argon in phengite from eclogite: Evidence from dating of eclogite minerals by $\mathrm{Sm}-\mathrm{Nd}, \mathrm{Rb}-\mathrm{Sr}$ and ${ }^{40} \mathrm{Ar} /{ }^{39} \mathrm{Ar}$ methods. Chem. Geol., v.112, pp.343-350.

Liou, J. G. and Zhang, R. Y., 1996, Occurrences of intergranular coesite in ultrahigh-P rocks from the Sulu region, eastern China: Implications for lack of fluid during exhumation. Am. Mineral., v.81, pp.1217-1221.

Liou, J. G., Maruyama, S. and Ernst, W. G., 1997, Seeing a mountain in a grain of garnet. Science, v.276, pp.48-49.

Magaritz, M., 1991, Carbon isotopes, time boundaries and evolution. Terra Nova, 3: 251-256.

Marshall, J. D. and Middleton, J. D, 1990, Changes in marine isotopic composition and the late Ordovician glaciation. J.Geol. Soc., London, v.147, pp.1-4.

Okay, A. I., 1993, Petrology of a diamond and coesite-bearing metamorphic terrain: Dabie Shan, China. Eur. J. Mineral., v.5, pp.659-675.

Okay, A. I., Xu, S. T. and Sengor, A. M. C., 1989, Coesite from the Dabie Shan eclogites, central China. Eur. J.Mineral., v.1,pp.595-598.

Ripperdan, R. .L., 1994, Global variations in carbon isotope composition during the latest Neoproterozoic and earliest Cambrian. Ann. Rev. Earth Planet. Sci., v.22, pp.385-417.

Rosenbaum, J. M. and Mattey, D., 1995, Equilibrium garnet-calcite oxygen isotope fractionation. Geochim. Cosmochim. Acta, v.59, pp.2839-2842.

Schertl, H. P. and Okay, A. L., 1994, A coesite inclusion in dolomite in Dabie Shan, China: Petrological and rheological significance. Eur. J. Mineral., v.6, pp. $995-1000$.

Sharp, Z. D., Essene, E. J. and Hunziker, J. C., 1993, Stable isotope geochemistry and phase equilibria of coesite-bearing whiteschists, Dora Matra Massif, western Alps. Contrib. Mineral. Petrol., v.114, pp.1-12.
Stiller, M., Rounick, J. S. and Shasha, S., 1985, Extreme carbone-isotope enrichments in evaporating brines. Nature, v.316, pp.434-435.

Valley, J. W., 1986, Stable isotope geochemistry of metamorphic rocks. Rev. Mineral., v.16, pp. $445-489$

Wang, X. M. and Liou, J. G., 1991. Regional ultrahigh-pressure coesite-bearing eclogitic terrane in central China: Evidence from country rocks, gneiss, marble and metapelite, Geology, v.19, pp.933-936.

Wang, X., Liou, J. G. and Mao, H. K., 1989, Coesite-bearing eclogite from the Dabie Mountains in central China. Geology, v.17, pp.1085-1088.

Wang, X. M., Zhang, R. Y. and Liou, J. G., 1995, UHPM terrane in east central China. In R.G. Coleman and X. M. Wang (eds. ), Ultrahigh Pressure Metamorphism, Cambridge University Press, pp. 356-390.

Xu, S. T., Okay, A. I., Ji, S. Y., Sengor, A. M. C., Su, W., Liu, Y. C. and Jiang, L. L., 1992, Diamond from the Dabie Shan metamorphic rocks and its implication for the tectonic setting. Science, v.256, pp.80-82.

Yui, T. F., Rumble III, D. and Lo, C. H., 1995, Unusually low $\delta^{18} \mathrm{O}$ ultrahigh-pressure metamorphic rocks from the Su-Lu Terrain, eastern China: Geochim, Cosmochim. Acta, v.59, pp.2859-2864.

Zhang, R. Y., Hirajima, T., Banno, S., Cong, B. L. and Liou, J. G., 1995, Petrology of uitrahigh-pressure rocks from the southern Su-Lu region, eastern China: J. Metamorph. Geol., v.13, pp.659-675.

Zhang, R. Y. and Liou, J. G., 1996, Coesite inclusions in dolomite from eclogite in the southern Dabie Mountains, China: The significance of carbonate minerals in UHPM rocks: Am. Mineral., v.81, pp.181-186.

Zheng, Y. F., Fu, B., Gong, B. and Li, S. G., 1996, Extreme $\delta^{18} \mathrm{O}$ depletion in eclogite from the Su-Lu terrane in East China: Eur. J. Mineral., v.8, pp. $317-323$.

Zheng Yongfei is a professor of geochemistry and the Dean of the Department of Earth and Space Sciences, University of Science and Technology of China, Hefei. He graduated from Nanjing University in 1981 and obtained his Ph.D. from University of Goettingen, Germany in 1991. He has been specialized in the theoretical calculations and experimental measurements of isotope fractionation factors, theoretical modelling of isotopic systematics and applications to geochemistry of petrogenesis and metallogenesis, chemical geodynamics of orogenic rocks.

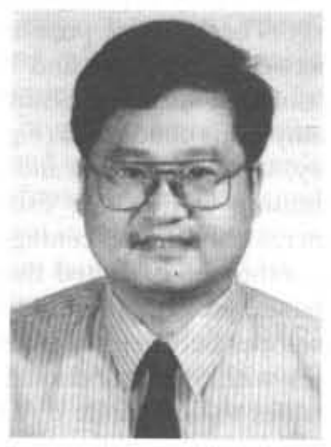

